\title{
The Life Cycle Assessment and Life Cycle Cost in public works contracts
}

\author{
Beata $\mathrm{Grzyl}^{1,{ }^{*}}$ and Agata Siemaszko ${ }^{1}$ \\ ${ }^{1}$ Faculty of Civil and Environmental Engineering, Gdansk University of Technology (GUT), \\ Narutowicza 11/12, 80-233 Gdansk, Poland
}

\begin{abstract}
An important goal, implemented by EU countries under the Europe 2020 strategy, is sustainable development, which includes supporting economy that effectively uses natural and environmentally friendly resources. Solutions in this area are also promoted in tender proceedings in the area of public procurement. The LCA (Life Cycle Assessment) and LCC (Life Cycle Cost) analysis are indicated as the basis for decision-making by awarding entities. In the article, the authors present on the selected example the benefits of using LCA and LCC. Based on the documents analysis for 350 selected public procurement procedures conducted in Poland in 2017, the authors examine types, average weights and frequency of application of non-price criteria for the selection of the best offer in practice. Based on the results of the research, are formulated conclusions.
\end{abstract}

\section{Introduction}

The basic legal acts regulating the public procurement policy in the EU are Directives $[1,2]$. The recommendations contained in them provide for numerous opportunities to promote environmental protection and sustainable economy development. The contracting authority has great freedom to choose a product, service or object that intend to purchase, while having the freedom to set the criteria for their selection.

The sustainable development policy currently promoted by EU recommends reducing the environmental impact of objects, products or services to the minimum necessary at all stages of their life cycle. Such an approach generates real environmental gains (it allows to identify solutions that will have the least impact on global warming, exhaustion of fossil fuels, smog formation, depletion of the ozone layer, water consumption), also leads to a reduction in production costs, use and disposal of products [3, 4]. It can therefore be concluded that the LCA (Life Cycle Assessment) technique, allowing for a comprehensive assessment of the environmental impact of a product or service produced, is closely related to the Life Cycle Cost Analysis (LCC).

\footnotetext{
*Corresponding author: beata.grzyl@pg.edu.pl
} 


\section{Public Procurement Law in the aspect of applying environmental criteria and the life cycle cost of a building}

Pursuant to the PPL Act (Public Procurement Law) [5], when making orders for the design and implementation of construction works, public procurers may use environmental and cost criteria referring to the next stages of the object's life cycle [6].

Examples of possible, practically applicable criteria for the evaluation of offers, referring to environmental aspects, but also related to the costs of operating the subject of the contract include [7,8]:

- energy consumption, which allows to reduce the consumption of natural resources and environmental pollution in the energy production process and reduce operating costs of the contract; the contracting authority may require a certain energy efficiency of the equipment (with lower energy consumption) or certain parameters of the energy performance of the building (reduction of heat energy consumption due to the use of appropriate technologies and technical solutions),

- consumption of media and consumables, whose production or disposal is harmful to the environment,

- the application of finishing materials and limiting the frequency of the maintenance operations for the cleaning elements of the building,

- using innovative solutions to extend the period of equipment operation and reduce service activities,

- recycling of solid waste and sewage,

- the possibility to purify the gases coming from the facility, the application of technologies that do not cause (or cause less) atmosphere pollution,

- the application of materials whose production is neutral or little harmful to the environment, for which no toxic chemicals are used, can be recycled or biodegradable and come from a sustainable economy,

- the use of trenchless technology in the implementation of underground installations.

\subsection{LCA - assumptions and benefits resulting from the application}

The LCA technique is one of the tools of environmental management, it allows for the ecological (environmental) assessment of technologies, products and services.

It enables assessment of their impact on the environment in individual phases of the life cycle, including: extraction and processing of mineral resources, production in the manufacture process, distribution, transport, use, recycling, reuse, and waste utilization.

The LCA technique is applied when assessing production technologies or solutions in the field of product and waste management systems and their impact on the environment. Thanks to the obtained results it is possible to determine the least onerous solution for the environment and indicate the most effective resources management in ecological and economic terms. The LCA analysis also allows determining the scope and impact of the product and object on human health.

The main cause of environmental pollution is the production of heat and electricity from non-renewable sources. Energy sources account for over $50 \%$ of air emissions in Poland [4]. It is therefore justified to use the LCA analysis to determine the impact of individual sources (coal, natural gas, crude oil, fuel oil) on adverse environmental effects [9].

It is also possible to apply environmental criteria for the evaluation and selection of the best offer in the area of public procurement. There are many certification and building assessment models that can be applied as environmental criteria for selecting the best offer, 
e.g. BREEAM (Building Research Establishment Environmental Assessment Method), LEED (Leadership in Energy and Environmental Design) or DGNB (Deutsche Gesellschaft für Nachhaltiges Bauen).

\subsection{LCC - assumptions and benefits of using}

The LCC method is based on calculating the total cost of a product, facility, service, generated in the period from obtaining raw materials to waste management, taking into account the design, installation, operation, maintenance, recycling or utilization phases [10].

All costs incurred during the life cycle of a building consist of a life cycle costing. According to art. 91 par. 3c of PPL [5], this is the cost of: acquisition, use, maintenance and decommissioning (demolition and recycling).

The LCC analysis can be carried out in two ways [11, 12]: a simple method for simple comparisons and a complex method, including the analysis of discounted cash flows.

The choice of the appropriate method depends on the size and complexity of the project. According to [13], approximately $80-90 \%$ of running costs incurred in the implementation and operation of the facility are determined at the design stage. The LCC carried out for various variants of construction and operation of a building is therefore the basis for making effective investment decisions [14]. In combination with the LCA analysis, it also has a significant impact on increasing the environmental performance of the adopted variant.

\section{Benefits of using LCA and LCC on an example}

The benefits of using in public works contracts in the public sector, criteria that take into account environmental aspects and the life cycle cost of an object, should be considered in the broad perspective. If the object of the contract is construction of a new or renovation of an existing facility, various options should be analyzed [15], taking into consideration the scope of its impact on the environment (LCA analysis) and the life cycle cost (LCC analysis). The comparison of investment outlays and long-term operational costs gives the client a full picture of the total costs associated with the purchase, maintenance and use of the object.

Table 1 presents examples of construction costs, total annual operating and energy costs and discounted life cycle costs for a six-storey office building with a usable area of $2,124.00 \mathrm{~m}^{2}$, implemented in various standards [16].

The results of the LCC analysis (Table 1) indicate that the low initial costs associated with the implementation of the facility in the basic standard, in the long-term, in the course of its operation, mean for the investor higher costs associated with its maintenance and use [16]. The LCA analysis also allows to state that with the increase in the standard of the operated facility, the emission of $\mathrm{CO}_{2}$ to the atmosphere decreases. As a result of the combined analyzes (LCA and LCC), it is possible for the investor to choose a solution that is beneficial from the environmental impact point of view, but also effective in terms of expenses incurred in the long run. High expenditures incurred on energy-saving solutions will have an economic and environmental effect in the long-term. It is possible to achieve savings in operating and energy costs for a building with the highest standard of about $35 \%$ compared to the basic standard and reduce its $\mathrm{CO}_{2}$ emissions to the atmosphere by about $15 \%$. 
Table 1. The comparative analysis for an office building implemented in various standards [16].

\begin{tabular}{|c|c|c|c|c|c|c|}
\hline $\begin{array}{c}\text { The standard } \\
\text { of the building }\end{array}$ & $\begin{array}{c}\text { The } \\
\text { construction } \\
\text { cost } \\
\text { [PLN] }\end{array}$ & $\begin{array}{c}\text { Annual } \\
\text { operating } \\
\text { cost (service, } \\
\text { ongoing } \\
\text { maintenance } \\
\text { of } \\
\text { installations) } \\
\text { [PLN/year] }\end{array}$ & $\begin{array}{c}\text { Annual } \\
\text { energy cost } \\
\text { [PLN/year] }\end{array}$ & $\begin{array}{c}\text { Total } \\
\text { annual } \\
\text { operating } \\
\text { and energy } \\
\text { costs } \\
\text { [PLN/year] }\end{array}$ & $\begin{array}{c}\text { Discounted } \\
\text { cost in the } \\
\text { life cycle } \\
\text { [PLN/year] }\end{array}$ & $\begin{array}{c}\text { Annual } \\
\text { emission } \\
\text { CO2 } \\
\text { [t/year] }\end{array}$ \\
\hline $\begin{array}{c}\text { Standard } \\
\text { building }\end{array}$ & 5632136.00 & 25920.00 & 34554.00 & 60474.00 & 7852979.9 & 126.9 \\
\hline $\begin{array}{c}\text { Standard } \\
\text { building }\end{array}$ & 5771312.00 & 25920.00 & 26950.00 & 52870.00 & 7712907.0 & 97.4 \\
\hline $\begin{array}{c}\text { A high standard } \\
\text { building }\end{array}$ & 6062976.00 & 27920.00 & 14800.00 & 42720.00 & 7631822.9 & 44.6 \\
\hline $\begin{array}{c}\text { A building with } \\
\text { a very high } \\
\text { standard }\end{array}$ & 6095500.00 & 28420.00 & 9484.00 & 37904.00 & 7487484.4 & 24.2 \\
\hline $\begin{array}{c}\text { A building with } \\
\text { a very high } \\
\text { standard with } \\
\text { solar collectors }\end{array}$ & 6175510.00 & 32420.00 & 8059.00 & 40479.00 & 7662058.6 & 18.2 \\
\hline $\begin{array}{c}\text { A building with } \\
\text { a very high } \\
\text { standard with } \\
\text { a heat pump }\end{array}$ & 6297821.00 & 8500.00 & 8592.00 & 21815.00 & 7098956.7 & 17.9 \\
\hline
\end{tabular}

The life-cycle costing of a building is therefore the basis for making rational and longterm investment decisions, but also has an impact on improving environmental performance.

Increasing the initial capital expenditure related to raising the building energy standard in the long-term perspective, results in lowering current costs in the building life cycle and increasing the final value of the property.

\section{The analysis of selected procedures for construction works in the aspect of applied in practice evaluation criteria}

The use of LCA and LCC analysis by public procurers at the stage of assessing and selecting the best offer generates undeniable benefits.

In justified cases, the need for their use would seem to be obvious. The authors present three selected examples of proceedings together with the criteria for the assessment of offers accepted by the awarding entities.

\section{Example 1}

Thermo-modernization of the Primary School no. 172 as part of the project entitled "Rationalization of energy consumption - thermo-modernization of educational facilities of the City of Lodz" co-financed by EU [17]. The goal of the project, carried out in the period of 2014-2020, is to support the energy in modernization of educational institutions in the City of Lodz. The investments implemented as part of the project contribute to the reduction of energy demand. The effect will be the reduction of the conventional fuels consumption and reduce the air pollutants. It is assumed that the implementation of the investment will allow to increase the energy efficiency of 70 buildings by at least $25 \%$.

The tender evaluation criteria applied by the awarding entity [17]:

- the price: $60 \%$ weight, 
- the guarantee and warranty for performed work (additional guarantee period and warranty for work performed over 60 months): weight $20 \%$,

- the deadline for completion (shortening the deadline for performing the contract): weight $20 \%$.

\section{Example 2}

The venture "Reconstruction of the heating network in Łódź in order to reduce $\mathrm{CO}_{2}$ emissions and improve energy efficiency" includes the implementation of measures to optimize heat consumption through the exchange and reconstruction of heating networks located in Łódź together with the implementation of the heat management and supporting infrastructure [18]. The effects of the activities will include reducing heat loss, increasing distribution efficiency, reducing the amount of consumed fuel and $\mathrm{CO}_{2}$ emissions to the atmosphere.

The tender evaluation criteria applied by the awarding entity [18]:

- the gross price: $80 \%$ weight,

- the warranty period for pre-insulated materials together with assembly robots, including sealing of the connectors units: weight $20 \%$.

\section{Example 3}

Investment "Reconstruction and extension of sewage treatment plant in Unieście" implemented as part of the program "Economic and environmental rationalization of the sewage treatment system in the commune of Mielno - stage I - reconstruction and extension of sewage treatment plant in Unieście". The aim of the project is to protect the natural environment and organize wastewater management (domestic and industrial wastewater) in the Mielno agglomeration.

The implementation of the investment will contribute to the protection of water resources in the Koszalin district and the zachodniopomorskie voivodeship, protection and preservation of the ecological status of the Baltic Sea and Lake Jamno [19].

The tender evaluation criteria applied by the awarding entity [19]:

- the price: $100 \%$ weight.

\section{Example 4}

The investment "Renovation of the forestry house in Sławutkowo". The ordering party was the State Treasury, the State Forest Holding, the State Forests, the Wejherowo Forest

District.

The contract scope of the subject included: the replacement of the roof structure with the covering, replacement of gutters and downpipes, installation of roof windows, implementation of a new electrical installation and painting of the façade. The tender evaluation criteria applied by the awarding entity [20]:

- the price: weight: $60 \%$,

- the quality warranty period: $10 \%$ weight,

- deadline for completion of construction works: 5\% weight,

- social aspects: 5\% weight,

- environmental aspects: $10 \%$ weight.

As part of the criterion regarding environmental aspects, the contracting authority provided two sub-criteria. The first concerned exhaust emissions in vehicles used by the contractor during construction works. The criterion has been referred to the Euro 5 standard, specifying the permissible level of exhaust emissions in vehicles. The second sub-criterion concerned the limitation of difficulties and nuisances in public traffic by using a washing system for wheels and chassis of vehicles leaving the construction field on public roads.

In order to make a broader analysis and determine the types and frequency of application of the criteria for the evaluation and selection for construction works best offer used by Polish awarding entities, the authors carried out research. The analysis 
of 350 proceedings worth over the EU thresholds carried out in the I quarter of 2017 IV quarter of 2017 in the mode of unlimited and restricted tenders. The sources of information were notices contained in the Public Information Bulletin of the Public Procurement Office on the basis of [21] on proceedings for construction works carried out in the "build" and "design and build" systems. Table 2 presents the results of the study criteria used by awarding entities, their average weights and the frequency of application of a given criterion.

Table 2. The criteria for the evaluation and selection of the best offer applied by awarding entities in Poland for selected tender procedures.

\begin{tabular}{|c|c|c|}
\hline $\begin{array}{l}\text { The criterion used for the assessment } \\
\text { and selection of the best offer }\end{array}$ & $\begin{array}{c}\text { The average } \\
\text { weight of a given } \\
\text { criterion [\%] }\end{array}$ & $\begin{array}{c}\text { Percentage } \\
\text { of proceedings involving } \\
\text { a given criterion }[\%]\end{array}$ \\
\hline Price & 59.3 & 100 \\
\hline Deadline for implementation & 47.2 & 34.3 \\
\hline $\begin{array}{c}\text { Guarantee period (warranty), conditions } \\
\text { for extension, etc. }\end{array}$ & 44.1 & 43.4 \\
\hline $\begin{array}{l}\text { Quality, functionality, technical parameters } \\
\text { of the object }\end{array}$ & 29.2 & 20.2 \\
\hline $\begin{array}{l}\text { Knowledge, experience, professional } \\
\text { qualifications of the contractor }\end{array}$ & 28.4 & 21.7 \\
\hline Conditions, terms of payment & 22.6 & 21.7 \\
\hline Organization, planning, consistency of tasks & 10 & 1.4 \\
\hline $\begin{array}{c}\text { Social aspects } \\
\end{array}$ & 10 & 1.4 \\
\hline Environmental aspects & 5 & 0.3 \\
\hline $\begin{array}{l}\text { Quality, functionality, technical parameters of } \\
\text { the applied solutions, proposed technologies } \\
\text { and materials }\end{array}$ & 5 & 0.6 \\
\hline The analysis of the life cycle costs of the object & - & 0 \\
\hline $\begin{array}{c}\text { Architectonic approach (using Building } \\
\text { Information Modeling) }\end{array}$ & - & 0 \\
\hline Risk management & - & 0 \\
\hline Innovation & - & 0 \\
\hline
\end{tabular}

source: own study

The analysis justifies the formulation of the following conclusions.

1. The Directives $[1,2]$ applicable in the EU countries promote the use of numerous nonprice criteria for the offers evaluation. However, the results of the analysis indicate that Polish contracting entities do not use this option. In tender procedures, one or two non-price criteria are applied (performance deadline, warranty period). In case of applying other criteria (facility functionality, contractor's experience, payment conditions), they have a low weight, which means that they do not have a significant impact on the final assessment and selection of the best offer. The social and environmental criteria are also not widely applied. In practice, there is no criterion of the object life cycle cost, BIM application, risk management or innovation of the proposed solutions or technologies.

It can be stated that the price proposed by the contractor in the submitted offer is still decisive in the majority of cases.

2. In practice, the use of non-price criteria such as the impact on the environment or the cost of the life cycle of the object is a very "troublesome" solution for the ordering parties. It increases the cost and workload of the contracting entity in the preparation and conduct of the proceedings, necessitates a precise description of the contract subject and precise definition of the essential features of the facility (e.g. the innovative character), extends 
the procedure for assessing submitted offers, increases the likelihood of questioning a selection result by the tenderers.

\section{Conclusions}

In addition to the numerous benefits of placing orders, taking into account environmental criteria related to the life cycle costs of the facility (sections 1, 2, 3), it is also necessary to pay attention to the possibility of effective and rational spending of public funds.

The manifestation of this will undoubtedly be the public procurement of supplies, services and construction works, which in the longer life cycle generate lower costs related to their maintenance and use.

In the authors opinion, the LCA and LCC analysis is a useful tool to determine the actual value of the subject of the contracts, taking into account the cost of purchase, maintenance, use and utilization. By promoting tendering solutions affecting the environment and life-cycle costs of a building, as well as the application of reasonable evaluation and selection criteria, contracting entities have an impact on design solutions and applied technologies, and as a result on the parameters of a future building.

The widespread use of these non-price criteria for the selection of offers is, however, an extremely difficult task in the aspect of public procurement. In some cases, meeting certain environmental requirements is an obligatory condition. This may result, for example, from legal provisions, requirements set in administrative decisions regarding the implementation of the contract subject (e,g. environmental conditions). In other cases, this is not an obligatory activity - it results from the will of the ordering party. An important barrier to their application are the previous practices and habits of the ordering parties.

There is also no recommended and uniform methodology for calculating the life-cycle cost of an object and estimating the value of certain factors affecting the environment, difficult to calculate unambiguously (e.g. the climate change, soil or water acidification).

This causes justified fears of the ordering parties regarding the possibility of making a discretionary choice of the most advantageous offer.

\section{References}

1. Dyrektywa Parlamentu Europejskiego i Rady 2014/24/UE z dn. 26 lutego 2014 r. w sprawie zamówień publicznych, uchylająca dyrektywę 2004/18/WE

2. Dyrektywa Parlamentu Europejskiego i Rady 2014/25/UE z dn. 26 lutego 2014 r. w sprawie udzielania zamówień przez podmioty działające w sektorach gospodarki wodnej, energetyki, transportu i usług pocztowych, uchylająca dyrektywę 2004/17/WE

3. http://ekoinnowator.ue.poznan.pl/files/Aspekty_ekoinnowacyjne_jako_kryterium_ocen y_ofert_w_prawie_zam\%C3\%B3wien_publicznych_K_Rozowicz.pdf; last accessed $2017 / 1 \overline{1} / 1 \overline{2}$

4. http://www.ztch.umcs.lublin.pl/materialy/rozdzial_25.pdf; last accessed 2017/11/03

5. Obwieszczenie Marszałka Sejmu Rzeczypospolitej Polskiej z dnia 20 lipca 2017 r. w sprawie ogłoszenia jednolitego tekstu ustawy - Prawo zamówień publicznych Dz. U. 2107, poz. 1579; last accessed 2017/11/15

6. https://ec.europa.eu/docsroom/documents/5054; last accessed 2017/11/10

7. http://ec.europa.eu/DocsRoom/documents/5058/attachments/1/translations/en/rendition s/pdfhttp://ec.europa.eu/environment/gpp/pdf/criteria/office_building_design/PL.pdf; last accessed 2017/11/15

8. D. Kowalski, B. Grzyl, A. Kristowski, CEER 26, 3 (2017) 
9. http://ec.europa.eu/environment/gpp/pdf/handbook_pl.pdf; last accessed 2017/11/15

10. E. Plebankiewicz, K. Zima, D. Wieczorek, ACE 62, 2 (2016)

11. PN-EN 63300-3-3 Zarządzanie niezawodnością część 3-3: Przewodnik zastosowań. Szacowanie kosztu cyklu życia (2006)

12. ISO 15686-5:2008 Buildings and constructed assets: Service - life planning. Part 5: Life-cycle costing

13. https://www.parp.gov.pl/files/74/81/469/12973.pdf; last accessed 2017/12/12

14. B. Grzyl, A. Kristowski, K. Jamroz, A. Gobis, MATEC Web Conf. 122, 02003 (2017)

15. M. Apollo, E. Miszewska-Urbańska, Advances in Science and Technology Research Journal 9, 28 (2015)

16. A. Węglarz, Krajowa Agencja Poszanowania Energii S.A., http://cdn13.muratorplus.smcloud.net/t/myfile/Arkadiusz_Wglarz.pdf; last accessed 2017/12/11

17. http://przetargi.bip.uml.lodz.pl/pokaz/plik.htm;jsessionid=8497164A9EDFA3C850EB C3127DB7FDAC?idPlik=28042; last accessed 2017/12/01

18. http://www.energiadlalodzi.pl/przebudowa-sieci-cieplowniczej-w-lodzi-w-celuograniczenia-emisji-co2-i-poprawy-efektywnosci-0; last accessed 2017/12/15

19. http://www.zwkuniescie.bip.net.pl/?a=296; last accessed 2017/12/01

20. http://bip.lasy.gov.pl/pl/bip/dg/rdlp_gdansk/nadl_wejherowo; last accessed 2017/12/15

21. https://www.bip.gov.pl; last accessed 2017/12/15 